Journal of Applied Fluid Mechanics, Vol. 3, No. 1, pp. 47-54, 2010.

Available online at www.jafmonline.net, ISSN 1735-3572, EISSN 1735-3645.

DOI: $10.36884 / \mathrm{jafm} .3 .01 .11878$

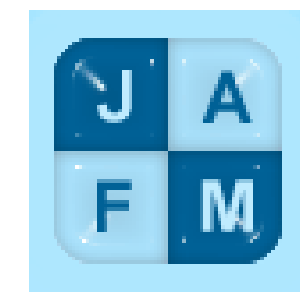

\title{
Biomass Position for Renewable Energies: Main Ways of Energetic Valorization
}

\author{
A. Zoulalian \\ Emeritus Professor, University of Nancy, LERMAB-BP 70239 54500-Vandoeuvre les Nancy-France \\ Email: andre.zoulalian@lermab.uhp-nancy.fr
}

(Received February 25, 2009; accepted March 28, 2009)

\begin{abstract}
The growth of some pollutants such as carbon dioxide, methane, etc... in the atmosphere induces the rise of temperature on the earth and the rarefaction of fossil energies (coal, oil, natural gas, ...) and encourages the most industrial and developed countries, to promote renewable energies. Among these energies, biomass represents nowadays the main power supply (more than 50\%). If the biomass has allowed since the antiquity the production of heat, the recent researches are focused on the simultaneous production of electricity and fuels under different physic forms (solid, liquid or gas) such as methane and hydrogen. The objective of the manuscript is to precise the different energetic valorizations of biomass.
\end{abstract}

Keywords: Renewable energy, Biomass, Heat, Electricity, Fuel, Hydrogen.

\section{INTRODUCTION}

The warming up of the earth atmosphere is principally due to the growth of gaseous pollutants such as: $\mathrm{CO}$, $\mathrm{CH} 4, \mathrm{CF} 4 \ldots$ and encourages many countries to sign the Kyoto Protocol which aim is to limit the production of these gases. The risk of the depletion of the fossil energies (coal, oil, natural gas) that cause these pollutants get the most industrial and developed countries to search for new power supplies more perpetual and yet named renewable. Thus, in 2000, the EU (European Union) has written in a White Book the following objectives: double between the years 2000 and 2010, the part of renewable energies by bringing the ratio renewable energies / total energy production from $5.6 \%$ to $12 \%$ with the electricity part obtained from renewable energies close to $21 \%$. Even if these objectives will not be probably reached in 2010, the progression observed during the three last years is encouraging and the EU is surely the community of countries which will satisfy at best the Kyoto Protocol recommendations. Here, we will essentially focus our discussion to the European data. The first part of the publication deals with the whole of renewable energies and their contribution to the total consumption of energy. Biomass is definitely the main renewable energy. It represents in $2005,2 / 3$ of the renewable energies in EU. Unfortunately, the biomass valorization is essentially thermal. The production of electricity and fuels has to be emphasized. In the second part, the energetic valorization ways of biomass will be presented.

\section{Renewable Energies - Position of BiOMASS AMONG THE RENEWABLE ENERGIES}

Contrary to the fossil energies (coal, oil, natural gas, uranium) the renewable energies are composed of sources assumed to be unfailing, namely:

-sun

-wind

-water fall and marine power

-heat of earth

-biomass

Sometimes wastes are also considered as a renewable energy but they are generally associated with biomass.

, Eight types of renewable energies are known at
present:
$\begin{array}{lll}\text {-photovoltaic } & \text {-solid biomass } & \text {-thermal solar } \\ \text {-wind power } & \text {-biofuel } & \text {-hydropower }\end{array}$

-biogas - -geothermal 
Two new types of renewable energy are in development that are the concentrating solar power (from the sun) and the energy coming from seas and oceans. Renewable energies produce heat and /or electricity but at present time, the will is to favor the energies which produce directly or indirectly electricity like wind power, hydropower, photovoltaic cells, etc...

The data given below, concerning the EU, are drawn out of the Euro Observer revue (2006). The total energy production in EU in 2005 is estimated to 1756 Mtep $(1 \mathrm{Mtep}=4.181016 \mathrm{~J})$. The renewable energies represent 112.1 Mtep which correspond to $6.38 \%$ of the total energy. Figure 1 gives the distribution between the different energies. Table 1 and Fig. 2 summarize respectively the variation between 1990 and 2004 and the part in 2005 of the renewable energies production of the different countries of the EU. From this table and the Figs. 1 and 2, we assume that biomass represents almost $2 / 3$ of the renewable energies and that the part of renewable energies for the northern countries of the EU is higher than $10 \%$ of the total energy production .Nevertheless, heat remains the main production. Thus, for all of the European countries, the electricity produced from renewable energies represents less than $14 \%$ and Fig. 3 gives, for each country, the part of electricity. At present wind power knows a strong development and the contribution of biomass has to be increased. In the following part, we will precise the ways to reach this objective.

\section{The Different VALORIZATION WAYS OF THE BIOMASS (COLONNA 2006, BALLERINI 2006 )}

\subsection{The Biomass Resources}

In 2005, the energy produced from the three types of renewable energies obtained from the biomass was respectively:

Solid biomass $($ wood + wastes $)=64.1$ Mtep

$\begin{array}{lll}\text { biofuel } & = & 3.9 \text { Mtep } \\ \text { biogas } & = & 4.8 \text { Mtep } \\ \text { Total }= & 72.8 \text { Mtep }\end{array}$

Wood energy is the most important renewable energy and its natural resource comes mainly from the forest and also from wood industries. Only the by-products of the lumbered wood have to be used (small size wood, tree cutting, brushwood, copse wood, cork, etc...) because the timber has to be kept for to the industrial joinery and wood building.

For example, Table 2 summarizes the wooded areas of the 15 countries of the EU with the production of logs and wood energy in 2000 . The last column of the table gives the ratio between the wood energy and the logs production. For some countries of for which the logs production is higher than $10 \mathrm{Mm} 3$ (Austria, Spain, France) this ratio is close to 0.30 whereas in Germany, Finland and Sweden the ratio is only 0.15 . If for these three countries, the ratio increased from 0.15 to 0.30 , the energy would reached 20.8 Mtep which is equivalent to $260 \mathrm{Mm} 3$ of wood. According to ADEME, the production of $2000 \mathrm{~m} 3$ of wood energy involves the creation of one job. Thus, 130000 jobs could be created in different areas: harvesting, unlading, transport, conditioning, conducting and control of the boiler furnace. Moreover, a better forest exploitation will have an impact on the forest maintenance: reduce the risk of forest fire, maintain the hydrological balance, improve the landscape, etc....

\subsection{The Valorization by Dry Ways}

The valorization by dry ways corresponds to a thermochemical transformation with or without another reagent such as $\mathrm{O} 2, \mathrm{H} 2 \mathrm{O}$, and $\mathrm{CO} 2$.

More precisely, with the absence of these reagents and the presence of an inert gas (generally N2) wood (and all biomass) decomposes progressively with the increase of the temperature.

This transformation is named: pyrolysis. With the presence of oxygen, the pyrolysis gases are oxidized with a flame development: it is the biomass combustion. Without oxygen, but with the presence of steam or $\mathrm{CO} 2$, the pyrolysis compounds, at temperatures higher than $700^{\circ} \mathrm{C}$, are converted into light gases such as: $\mathrm{CO}, \mathrm{CO} 2, \mathrm{H} 2, \mathrm{H} 2 \mathrm{O}$. This transformation is named gasification. In the following parts, we precise the characteristics and the energetic objectives of these three types of transformation.

\subsubsection{Biomass Pyrolysis}

This step is essential because it occurs during the combustion and the gasification processes. With the increase of the temperature the following evolutions are observed and summarized in Fig. 5.

- For $\mathrm{T}<120^{\circ} \mathrm{C}$, water is discharged (drying process)

- For $120^{\circ} \mathrm{C}<\mathrm{T}<250^{\circ} \mathrm{C}$, hemicelluloses are decomposed with the formation of acids (formic, acetic) and alcohol (methanol)

- For $250^{\circ} \mathrm{C}<\mathrm{T}<500^{\circ} \mathrm{C}$, cellulose and lignin are decomposed with the formation of no incondensable gases $(\mathrm{CO}, \mathrm{CO} 2, \ldots)$ and condensable gases ( $\mathrm{H} 2 \mathrm{O}$, aromatic and polyaromatic compounds named tars)

- For $\mathrm{T}>500^{\circ} \mathrm{C}$, the tars are decomposed with the formation of a solid rich in carbon named char

The pyrolysis rate depends also on the pressure and on the distribution between incondensable gases, tar and char depends on two parameters:

the level of the temperature, $\mathrm{T}$

the temperature gradient $\Delta \mathrm{T} / \Delta \mathrm{t}$ 
Figure 6 gives the distribution between the three types of products as a function of two parameters.

For a moderate temperature and a low temperature gradient, the production of char is favored. For wood species, the char represents 20 to $30 \%$ of the initial dry mass. For a moderate temperature and a high temperature gradient, the production of tars is favored. For a high temperature and a high temperature gradient, the production of incondensable gases is favored. Table 3 gives the products distribution in the case of a fast pyrolysis at high temperature $\left(900^{\circ} \mathrm{C}\right)$

Incondensable gases can be used as fuels. They correspond to a medium-energetic fuel for which the Low Heating Value (LHV) is close to $25000 \mathrm{~kJ} / \mathrm{kg}$ of dry wood. Tars are in small quantity (lower than $5 \%$ of the initial dry mass). Their composition is complex and their elimination or transformation by cracking or reforming with steam or $\mathrm{CO} 2$ have to be considered. Tars are generally a viscous mixture, with a low stability and are difficult to stock and carry. Char which represents near to $15 \%$ of the dry mass with a LHV close to $3100 \mathrm{~kJ} / \mathrm{kg}$ is an appropriate fuel for cooking in many developing countries. Moreover, char can be sold as a reducing agent for some metallurgic processes and as an absorbent after activation by steam in order to increase the specific area to reach values upper than $1000 \mathrm{~m} 2 / \mathrm{g}$.

In industrial processes biomass pyrolysis is carried out in fixed beds and in continuous devices such as rotary kilns.

\subsubsection{Biomass Combustion}

Biomass, which is constituted principally of carbon, hydrogen and oxygen, is a natural fuel. Since the antiquity biomass has been used to generate heat. Among the renewable energies, it is the main way to generate heat. In France, more than 6 millions of dwellings use wood as total or partial heating system. The devices are open or closed fireplaces, stoves fed with logs or automatically with pellets. Manuel or automatic boilers fed with logs, pellets or wood chips can also supply a central heating.

Beyond of the domestic uses, wood combustion is carried out in continuous industrial and local boilers in towns and villages in the vicinity of a forest. In France, the ADEME Wood Energy Projects support financially the setting up of wood-boilers able to develop high energetic powers (several MW).

The development of the combustion includes two steps (Fig. 7):

- A pyrolysis step with a production of combustion gases and flame development

- A combustion step of the residual char without flame but where $\mathrm{CO}$ emissions are maximal.

In continuous heating devices fed with primary and secondary air, the $\mathrm{CO}$ contents are low and respect the regulation in force. However, the production of unburnt and flying ashes requires the treatment of the smokes before their discharge in the environment (setting of filtering devices such as cyclones, electrofilters or bagfilters).

The presence of silicium and alkaline salts in the ashes can generate their melting and the failure of some types of boilers (for example boilers with grates). For domestic uses, the generated heat can be is transmitted directly by radiation and indirectly by a liquid fluid heated in a heat exchanger. For industrial and urban boilers which provide energetic powers higher than 10 MW, co-generation systems are associated to boilers, as the steam produced is reduced in a multistage steam turbine in order to generate simultaneously heat and electricity. Figure 8 gives the principle schema of cogeneration cycle with a double steam expansion.

\subsubsection{Biomass Gasification}

Gasification is a thermochemical transformation where are associated the following steps: pyrolysis, reactions between hydrocarbons and char with steam and/or $\mathrm{CO} 2$. These last reactions are observed beyond $700^{\circ} \mathrm{C}$. For example, for the steam, the typical stoechiometries are:

$$
\begin{gathered}
\mathrm{C}+\mathrm{H}_{2} \mathrm{O} \rightarrow \mathrm{CO}+\mathrm{H}_{2} \\
\mathrm{C}_{x} \mathrm{H}_{y}+x \mathrm{H}_{2} \mathrm{O} \rightarrow x \mathrm{CO}+(x+y / 2) \mathrm{H}_{2}
\end{gathered}
$$

The reactions with $\mathrm{CO} 2$ are similar. With these reforming reactions, cracking reactions can be observed with the typical stoechiometry:

$$
\mathrm{C}_{x} \mathrm{H}_{y} \rightarrow x \mathrm{C}+\mathrm{y} / 2 \mathrm{H}_{2}
$$

The ideal result of the gasification is a total conversion of the biomass (outwards of the mineral compounds) in a gaseous mixture composed of the following compounds: $\mathrm{H} 2, \mathrm{H} 2 \mathrm{O}, \mathrm{CO}, \mathrm{CO} 2$.

The Shift reaction can occur between these four compounds, with the following stoechiometry:

$$
\mathrm{CO}+\mathrm{H}_{2} \mathrm{O} \rightarrow \mathrm{CO}_{2}+\mathrm{H}_{2}
$$

This ideal mixture is not always obtained directly and the gas has to be treated to eliminate:

- the residual tars and the char

- the mineral compounds present as aerosols

- $\quad$ the small quantities of $\mathrm{H} 2 \mathrm{~S}$ and NH3

The gasification devices (which powers are higher than $10 \mathrm{MW}$ ) are either co and counter current fixed beds, or simple or double fluidized beds, or co-current transported beds. In the last case, the operating temperature is upper than $1200^{\circ} \mathrm{C}$.

From the ideal mixture, after the steam condensation and the recovery of $\mathrm{CO} 2$ by pressure swing adsorption, we obtain the $\mathrm{CO}+\mathrm{H} 2$ mixture called synthetic gas. 
The synthetic gas is a fuel with a medium-energetic LHV. It can be valorized in a gas-engine or a gasturbine with the simultaneous production of heat, electricity and even refrigeration. However, the valorization can be different from the combustion one because the synthetic gas can be used to obtain several fuels by suitable catalytic reactions. In particular, we can quote:

- the methanol synthesis with copper and zinc catalysts:

$$
\mathrm{CO}+2 \mathrm{H}_{2} \rightarrow \mathrm{CH}_{3} \mathrm{OH}
$$

- the methane synthesis with nickel and ruthenium catalysts:

$$
\text { - } \mathrm{CO}+3 \mathrm{H}_{2} \rightarrow \mathrm{CH}_{4}+\mathrm{H}_{2} \mathrm{O}
$$

- the Fischer-Tropsch synthesis with iron an cobalt catalysts:

$$
n \mathrm{CO}+(n+2) \mathrm{H}_{2} \rightarrow \mathrm{C}_{n} \mathrm{H}_{2 n+2}+\mathrm{H}_{2} \mathrm{O}
$$

These three catalytic reactions are industrially carried out in fixed beds with a high pressure because during the reaction, the total number of gaseous molecules diminishes (see the stoechiometry). In the same way, the Shift reaction can be used to increase the hydrogen proportion in the synthetic gas and become an hydrogen source for hydrogen fuel-cells.

\subsection{Valorization by Liquid Ways}

At high temperatures and pressures, biomass can be made soluble in different organic solvents. The liquid obtained is a mixture of polymers which viscosity is high and which becomes solid at low temperature. After the first oil crisis this energetic way has been studied to provide a high-energetic fuel but the viscosity and the instability of the mixture have not allowed a direct valorization as heavy fuel. The hydro-cracking of the mixture was considered but this way has not been carried on.

Today, only three liquid ways know an industrial development, namely the production of ethanol from sugars, polysaccharids and ligno-cellulosic products, the production of biofuels from oil seeds and the production of bio-gas from organic wastes.

\subsubsection{Ethanol Production}

Ethanol is obtained by an aerobic fermentation of sugars with different selected microorganisms at fixed temperatures and pHs. For the sugars with the higher concentration in starch (corn, maize, etc...) an enzymatic hydrolysis occurs before the fermentation. As the main uses of sugars and cereals concern nutrition purposes (human and animal), the present developments do not have to compete with these nutritional priorities and concern only the production of ethanol from the ligno-cellulosic products, hemicelluloses and cellulose being extracted by acid hydrolysis. The residual lignin can be used as a fuel in the fermentation unit to supply the heat necessary to the distillation operation at the end of the fermentation. Ethanol can be used as a pure fuel or mixed with gasoline and also as anti-knock additive. Thus, it is converted in ethyl-tertiobutyl-ether (ETBE) by a following etherification reaction with the isobutene:

$$
\mathrm{CH}_{2} \mathrm{C}\left(\mathrm{CH}_{3}\right)_{2}+\mathrm{C}_{2} \mathrm{H}_{5} \mathrm{OH} \rightarrow \mathrm{CH}_{2} \mathrm{C}\left(\mathrm{CH}_{3}\right)_{2} \mathrm{OC}_{2} \mathrm{H}_{5}
$$

The LHV of ethanol and ETBE are respectively 21285 $\mathrm{kJ} / \mathrm{l}$ and $26910 \mathrm{KJ} / \mathrm{l}$ contrary to $32020 \mathrm{~kJ} . / \mathrm{l}$ for the standard gasoline. Table 4 gives the ethanol productions of EU for the years 2004 and 2005.

\subsubsection{Biodiesel Production}

The oil seeds used in human and animal feeding such as: colza oil, sun flower oil, soya oil, palm oil, etc... can be used as fuels directly or after a transesterification reaction where ethanol or methanol takes the place of glycerin chains. The biodiesel obtained has a LHV around $37000 \mathrm{~kJ} / \mathrm{kg}$ contrary to $42000 \mathrm{~kJ} / \mathrm{kg}$ for the standard gasoil. In EU, biodiesel is obtained essentially from colza seeds. Table 5 shows the biodiesel production in the years 2004 and 2005. We can observe a considerable growth during the year 2005. This growth expresses the will to increase biodiesel production in EU.

\subsubsection{Biogas Production}

The agricultural wastes, sewage sludge and municipal landfill are composed of wet biomass for which the bacterial anaerobic decomposition produces a gas with high methane and carbon dioxide contents. The gas can contain some sulfur compounds. After the purification process, the biogas is a fuel for which the valorization can be done in a boiler but also in gas engine or gas turbine which is higher than several MW. In this case, heat and electricity can be produced simultaneously. Table 6 gives the biogas production in EU during the years 2004 and 2005.

\section{CONClusion}

Biomass is and will remain during the next years the main renewable energy. By direct combustion, heat is produced but also electricity but with a poor output. In order to increase the electric production the biomass pyrolysis-gasification has to be considered. Indeed, the resulting gas can be used as a fuel in gas turbines for which the electric output is higher than to the electric output obtained in steam turbines. Moreover, after a purification process, the gas can become a synthetic gas for the catalytic production of methanol, syngas, gasoil and hydrogen which are fuels for car engines or hydrogen cells.

In the case of agricultural products, several valorizations can be suggested, namely the ethanol production by the aerobic fermentation of sugars and polysaccharids, the biodiesels production from the oil seeds and the methane production by the anaerobic fermentation of agricultural and municipal wastes.

Finally, thanks to its diversity, biomass can be valorized as an energy by many different ways. Nevertheless, in our point of view, the optimal valorization is probably 
the pyrolysis-gasification, because it is able to concern all kind of biomass. Moreover, it is the only way which enables to maximize the hydrogen production, as hydrogen remains for us the best energetic source and the fuel of the future decades.

\section{REFERENCES}

Ballerimi, D. (2006) Les biocarburants. IFP Publications-Editions Technip-Paris.
Colonna, P. (2006) La chimie verte-coordinateur Editions TECE-DOC. Lavoisier-Paris.

Deglise, X. (1982) Les conversions chimiques du boisRevue Forestière de France 34, 249-270.

Euro-Observer (2006) Etat des énergies renouvelables en Europe- 6éme bilan-.Paris-France (www.energies.renouvlables.org).

Table 1 Annual evolution of renewable energies in EU (unit: million tep).

\begin{tabular}{|l|c|c|c|c|c|c|c|}
\hline \multicolumn{1}{|c|}{ PAYS } & $\mathbf{1 9 9 0}$ & $\mathbf{1 9 9 5}$ & $\mathbf{2 0 0 0}$ & $\mathbf{2 0 0 1}$ & $\mathbf{2 0 0 2}$ & $\mathbf{2 0 0 3}$ & $\mathbf{2 0 0 4}$ \\
\hline Austria & 5,2 & 6,0 & 6,8 & 6,9 & 6,8 & 6,7 & 6,7 \\
\hline Belgium & 0,7 & 0,7 & 0,8 & 0,9 & 0,8 & 0,0 \\
\hline Denmark & 1,2 & 1,5 & 2,0 & 2,2 & 2,3 & 2,6 \\
\hline Finland & 5,3 & 6,1 & 8,0 & 7,8 & 8,1 & 8,2 & 8,7 \\
\hline France & 15,8 & 17,9 & 17,3 & 18,5 & 16,6 & 17,1 & 16,3 \\
\hline Germany & 6,3 & 7,5 & 10,8 & 12,0 & 13,0 & 13,5 & 13,2 \\
\hline Greece & 1,1 & 1,3 & 1,5 & 1,4 & 1,4 & 1,6 & 0,3 \\
\hline Ireland & 0,2 & 0,2 & 0,3 & 0,3 & 0,3 & 0,3 \\
\hline Italy & 6,5 & 7,7 & 9,9 & 10,1 & 9,7 & 10,3 & 11,2 \\
\hline Luxembourg & 0,0 & 0,0 & 0,1 & 0,1 & 0,1 & 0,1 & 0,1 \\
\hline Netherland & 1,0 & 1,1 & 1,8 & 1,9 & 2,1 & 2,1 & 1,7 \\
\hline Portugal & 3,3 & 3,3 & 3,3 & 4,1 & 3,6 & 4,3 & 3,8 \\
\hline Spain & 6,3 & 5,7 & 7,1 & 8,3 & 7,1 & 9,3 & 8,8 \\
\hline Sweden & 11,7 & 13,1 & 15,6 & 15,1 & 13,9 & 13,4 & 13,9 \\
\hline $\begin{array}{l}\text { United King } \\
\text { dom }\end{array}$ & 1,1 & 2,0 & 2,5 & 2,6 & 2,9 & 3,2 & 3,5 \\
\hline $\begin{array}{l}\text { Total } \\
\text { EU (15) }\end{array}$ & $\mathbf{6 5 , 7}$ & $\mathbf{7 3 , 3}$ & $\mathbf{8 8 , 1}$ & $\mathbf{9 2 , 0}$ & $\mathbf{8 8 , 7}$ & $\mathbf{9 3 , 6}$ & $\mathbf{9 3 , 2}$ \\
\hline
\end{tabular}

Table 2 Wood Energy in EU (WE = production in wood energy $)(L P=$ production in logs $)$

\begin{tabular}{|l|c|c|c|c|c|c|}
\hline \multicolumn{1}{|c|}{ PAYS } & $\begin{array}{c}\text { Area } \\
\text { (Mha) }\end{array}$ & $\begin{array}{c}\text { Forest } \\
(\mathbf{M h a})\end{array}$ & $\begin{array}{c}\text { Forest } \\
(\boldsymbol{\%})\end{array}$ & $\begin{array}{c}\text { LP } \\
\left(\mathbf{H m}^{\mathbf{3}}\right)\end{array}$ & $\begin{array}{c}\text { WE } \\
(\mathbf{M t e p})\end{array}$ & $\begin{array}{c}\text { WE } \\
\text { /LP }\end{array}$ \\
\hline Austria & 8,3 & 3,9 & 47 & 10,8 & 3,0 & 0,28 \\
\hline $\begin{array}{l}\text { Belgium + } \\
\text { Luxembourg }\end{array}$ & 3,3 & 0,7 & 21 & 3,7 & 0,3 & 0,08 \\
\hline Denmark & 4,2 & 0,5 & 12 & 1,6 & 0,9 & 0,56 \\
\hline Finland & 30,5 & 21,9 & 72 & 49,6 & 7,5 & 0,15 \\
\hline France & 55,0 & 15,3 & 28 & 32,9 & 9,8 & 0,30 \\
\hline Germany & 34,9 & 10,7 & 31 & 36,4 & 5,0 & 0,14 \\
\hline Greece & 12,9 & 3,6 & 28 & 0,5 & 0,9 & 1,80 \\
\hline Ireland & 6,9 & 0,7 & 10 & 2,2 & 0,2 & 0,09 \\
\hline Italy & 29,4 & 10,0 & 34 & 4,4 & 4,6 & 1,04 \\
\hline Netherland & 3,4 & 0,4 & 12 & 0,9 & 0,5 & 0,55 \\
\hline Portugal & 9,2 & 3,7 & 40 & 8,4 & 1,7 & 0,20 \\
\hline Spain & 49,9 & 14,4 & 29 & 12,4 & 3,6 & 0,29 \\
\hline Sweden & 41,2 & 27,1 & 66 & 54,3 & 8,3 & 0,15 \\
\hline United Kingdom & 24,2 & 2,8 & 12 & 7,4 & 1,0 & 0,13 \\
\hline Total \\
EU (15) & $\mathbf{3 1 3 , 3}$ & $\mathbf{1 1 5 , 7}$ & $\mathbf{3 7}$ & $\mathbf{2 2 5 , 5}$ & $\mathbf{4 7 , 3}$ & $\mathbf{0 , 2 1}$ \\
\hline
\end{tabular}

Table 3 Products distribution in the case of fast pyrolysis (Deglise, 1982).

\begin{tabular}{|c|c|}
\hline \multirow{4}{*}{ No condensable gases } & $\mathrm{CO}=36 \%$ \\
\cline { 2 - 2 } & $\mathrm{CO}_{2}=5 \%$ \\
\cline { 2 - 2 } & $\mathrm{H}_{2}=19,5 \%$ \\
\cline { 2 - 2 } & $\mathrm{CH}_{4}=10 \%$ \\
\cline { 2 - 2 } & $\mathrm{C}_{2} \mathrm{H}_{4}=3 \%$ \\
\cline { 2 - 2 } & $\mathrm{C}_{2} \mathrm{H}_{2}=3 \%$ \\
\hline Condensable gases & water + tars =10\% \\
\hline Residual solid & char + mineral salts $=10 \%$ \\
\hline
\end{tabular}


A. Zoulalian / JAFM, Vol. 3, No. 1, pp. 47-54, 2010.

Table 4 Ethanol production in the EU (in tons)

\begin{tabular}{|l|c|c|}
\hline \multicolumn{1}{|c|}{ PAYS } & $\mathbf{2 0 0 4}$ & $\mathbf{2 0 0 5}$ \\
\hline Spain & 202354 & 240000 \\
\hline Sweden & 56529 & 130160 \\
\hline Germany & 20000 & 120000 \\
\hline France & 80887 & 99780 \\
\hline Poland & 38270 & 68000 \\
\hline Finland & 3768 & 36800 \\
\hline Hungary & & 11840 \\
\hline Lihtuania & & 6296 \\
\hline Netherland & 11146 & 5971 \\
\hline Czeeh Republic & & 1120 \\
\hline Latvia & 9800 & 960 \\
\hline Total EU & $\mathbf{4 2 2 7 5 4}$ & $\mathbf{7 2 0 9 2 7}$ \\
\hline
\end{tabular}

Table 5 Biodiesel production in the EU (in tons)

\begin{tabular}{|l|c|c|c|c|}
\hline \multicolumn{1}{|c|}{ PAYS } & $\mathbf{2 0 0 4}$ & $\mathbf{2 0 0 5}$ & Difference & Growth \\
\hline Germany & 1035000 & 1669000 & 634000 & $61,3 \%$ \\
\hline France & 348000 & 492000 & 144000 & $41,4 \%$, \\
\hline Italy & 320000 & 396000 & 76000 & $23,8 \%$ \\
\hline Czech Republic & 60000 & 133000 & 73000 & $121,7 \%$ \\
\hline Poland & 0 & 100000 & 100000 & $49,1 \%$ \\
\hline Austria & 57000 & 85000 & 28000 & $420,0 \%$ \\
\hline Slovakia & 15000 & 78000 & 63000 & $461,5 \%$ \\
\hline Spain & 13000 & 73000 & 60000 & $1,4 \%$ \\
\hline Denmark & 70000 & 71000 & 1000 & $466,7 \%$ \\
\hline United Kingdom & 9000 & 51000 & 42000 & \\
\hline Slovenia & 0 & 8000 & 8000 & \\
\hline Estonia & 0 & 7000 & 7000 & \\
\hline Lithuania & 5000 & 7000 & 2000 & $40,0 \%$ \\
\hline Latvia & 0 & 5000 & 5000 & \\
\hline Greece & 0 & 3000 & 3000 & \\
\hline Malta & 0 & 2000 & 2000 & \\
\hline Belgium & 0 & 1000 & 1000 & \\
\hline Sweden & 1400 & 1000 & -400 & \\
\hline Cyprus & 0 & 1000 & 1000 & $-28,6 \%$ \\
\hline Portugal & $\mathbf{1 9 3 3 4 0 0}$ & $\mathbf{3 1 8 4 0 0 0}$ & $\mathbf{1 2 5 0 6 0 0}$ & \\
\hline Total EU & & & & $\mathbf{6 4 , 7} \%$ \\
\hline & & & & \\
\hline
\end{tabular}

Table 6 Biogas production in EU (in ktep)

\begin{tabular}{|c|c|c|c|c|c|c|c|c|}
\hline \multirow[b]{2}{*}{ PAYS } & \multicolumn{3}{|c|}{2004} & \multirow[b]{2}{*}{ TOTAL } & \multicolumn{3}{|c|}{2005} & \multirow[b]{2}{*}{ TOTAL } \\
\hline & $\begin{array}{c}\text { Landfill } \\
\text { gas }\end{array}$ & $\begin{array}{c}\text { Sewage } \\
\text { sludge gas }\end{array}$ & $\begin{array}{l}\text { Other } \\
\text { biogas }\end{array}$ & & $\begin{array}{c}\text { Landfill } \\
\text { gas }\end{array}$ & $\begin{array}{c}\text { Sewage } \\
\text { sludge gas }\end{array}$ & $\begin{array}{l}\text { Other } \\
\text { biogas }\end{array}$ & \\
\hline $\begin{array}{l}\text { United King } \\
\text { dom }\end{array}$ & 1327,0 & 177,6 & & 1504,0 & 1421,0 & 179,6 & & 1600,0 \\
\hline Germany & 573,2 & 369,8 & 351,7 & 1294,7 & 573,2 & 369,8 & 651,4 & 1594,4 \\
\hline Italy & 297,7 & 0,3 & 37,5 & $\mathbf{3 3 5 , 5}$ & 334,1 & 0,4 & 42,0 & 376,5 \\
\hline Spain & 219,1 & 52,4 & 23,6 & 295,1 & 236,5 & 56,8 & 23,6 & 316,9 \\
\hline France & 127,0 & 77,0 & 3,0 & 207,0 & 129,0 & 77,0 & 3,0 & 209,0 \\
\hline Netherlands & 67,1 & 53,8 & 28,9 & 149,8 & 59,8 & 50,7 & 29,6 & 140,1 \\
\hline Denmark & 13,8 & 19,8 & 55,6 & 89,3 & 14,3 & 20,5 & 57,5 & 92,3 \\
\hline Belgium & 56,3 & 9,7 & 7,8 & $\mathbf{7 3 , 8}$ & 56,3 & 9,7 & 7,8 & $\mathbf{7 3 , 8}$ \\
\hline $\begin{array}{l}\text { Czech } \\
\text { Republic } \\
\end{array}$ & 18,6 & 28,7 & 2,9 & 50,2 & 21,5 & 31,4 & 2,8 & 55,8 \\
\hline Poland & 21,5 & 23,9 & & 45,4 & 25,1 & 25,3 & 0,3 & 50,7 \\
\hline Austria & 11,8 & 19,1 & 14,5 & 45,4 & 11,8 & 19,1 & 14,5 & 45,4 \\
\hline Greece & 20,5 & 15,5 & & 36,0 & 20,5 & 15,5 & & 36,0 \\
\hline Ireland & 19,9 & 4,8 & 5,1 & 29,9 & 24,9 & 4,8 & 5,1 & $\mathbf{3 4 , 8}$ \\
\hline Sweden & 12,0 & 22,1 & 1,2 & 35,3 & 10,1 & 18,7 & 0,9 & 29,8 \\
\hline Finland & 16,6 & 9,9 & & 26,5 & 16,6 & 9,9 & & 26,5 \\
\hline Portugal & & & 4,5 & 4,5 & & & 10,0 & 10,0 \\
\hline Slovenia & 5,8 & 0,9 & & 6,6 & 6,0 & 0,7 & & 6,8 \\
\hline Luxembourg & & & 5,0 & $\mathbf{5 , 0}$ & & & 6,7 & 6,7 \\
\hline Slovakia & & 5,7 & 0,2 & 5,9 & & 5,7 & 0,2 & 5,9 \\
\hline Hungary & 0,7 & 2,6 & 0,2 & 3,5 & 0,8 & 2,9 & 0,2 & 3,8 \\
\hline Total EU & 2808,6 & 893,1 & 541,7 & 4243,3 & 2961,4 & 898,0 & 855,6 & 4715,0 \\
\hline
\end{tabular}




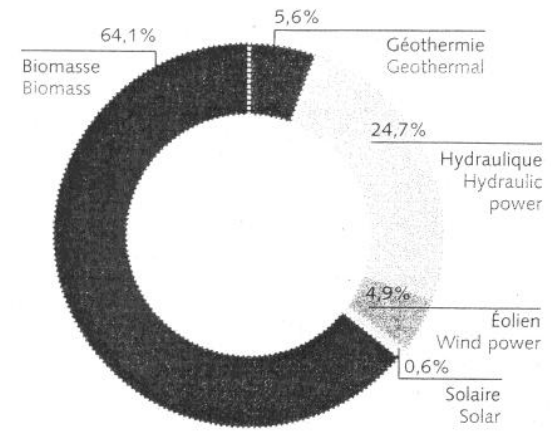

In 2004

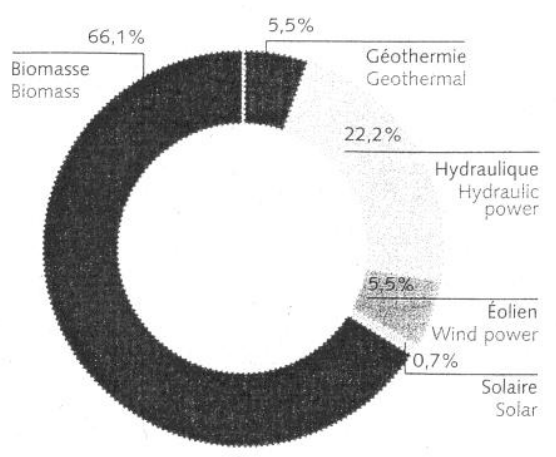

In 2005

Fig. 1. Share of each resource in the renewable primary energy production (in \%)

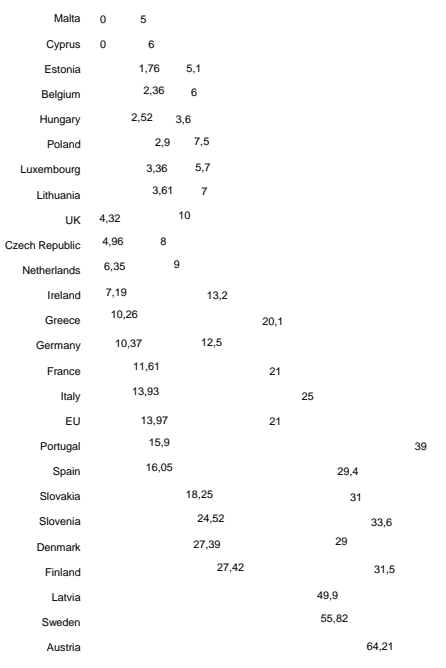

Fig. 3. Share of renewable energies in gross electrical consumption of the EU in 2005 (in \%)

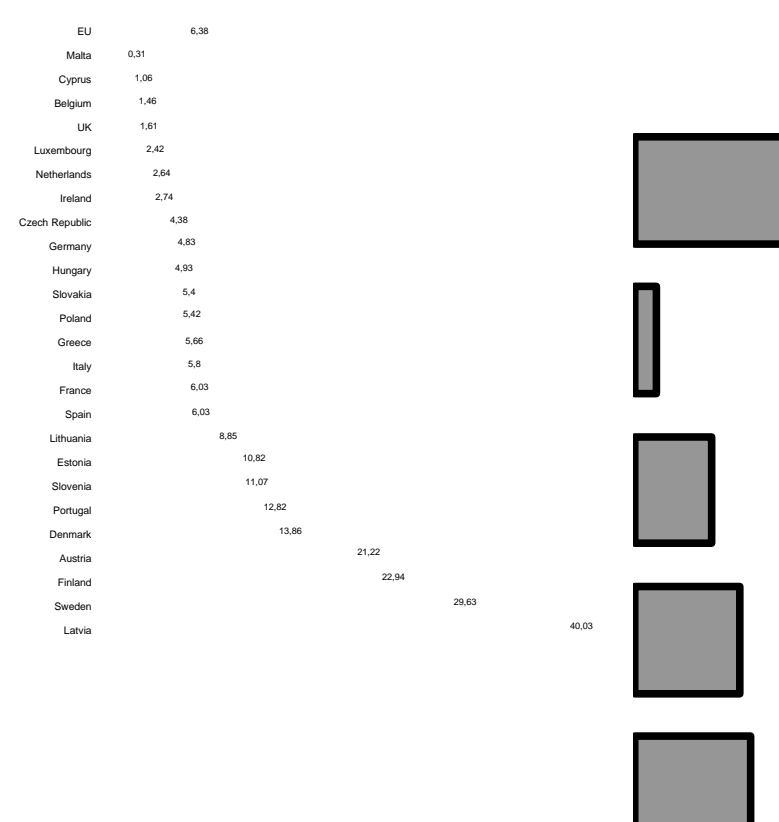

Fig. 2. Share of renewable energies in primary energy consumption of the EU in 2005 (in \%)

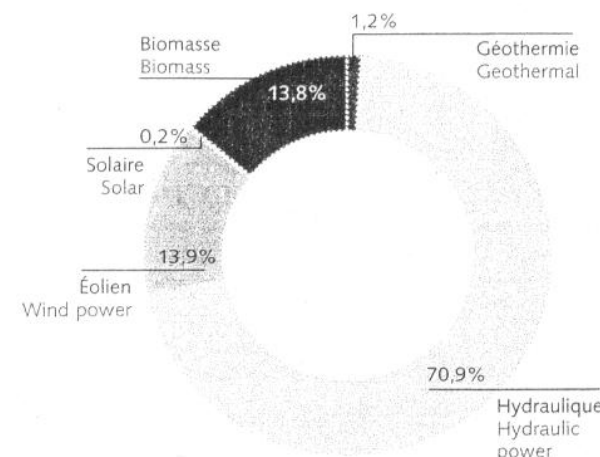

In 2004

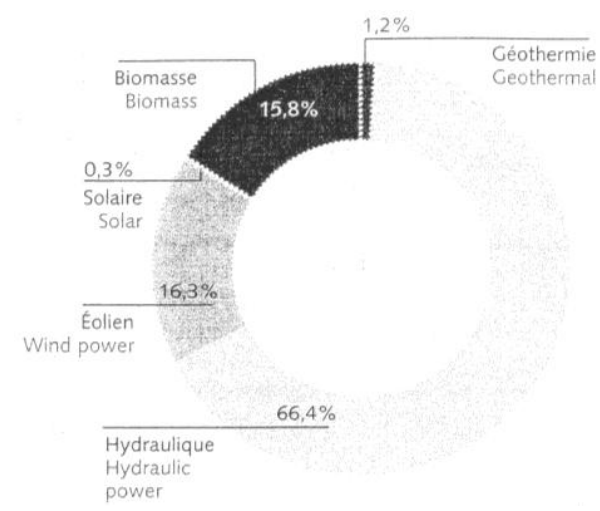

In 2005

Fig. 4. Share of each resource in renewable electricity generation (in \%) 


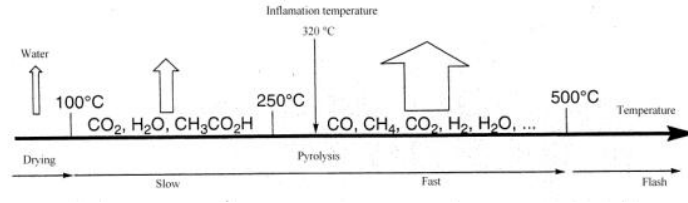

Fig. 5. Progress of pyrolysis with the increase of temperature

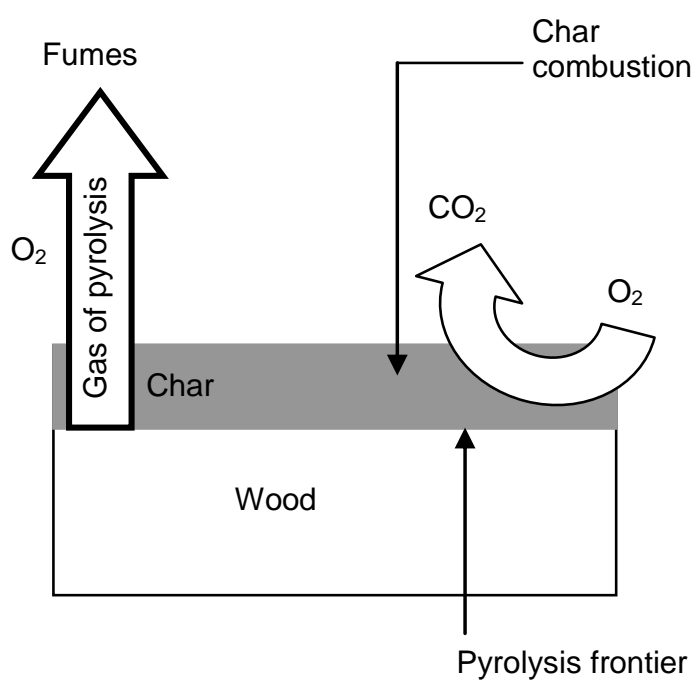

Fig. 7. Progress of wood combustion

$$
\mathrm{T}=500^{\circ} \mathrm{C}
$$

$\Delta \mathrm{T} / \Delta \mathrm{t}(\mathrm{K} / \mathrm{s})<1$

\begin{tabular}{|c|}
\hline$G$ \\
\hline$T$ \\
\hline$C$ \\
\hline
\end{tabular}
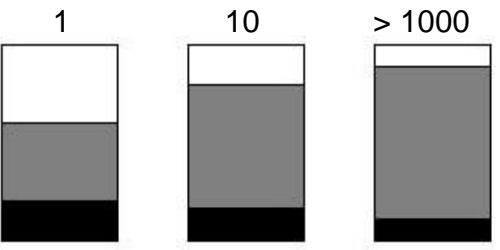

$\mathrm{T}=1000^{\circ} \mathrm{C}$

$\Delta \mathrm{T} / \Delta \mathrm{t}(\mathrm{K} / \mathrm{s})<1$
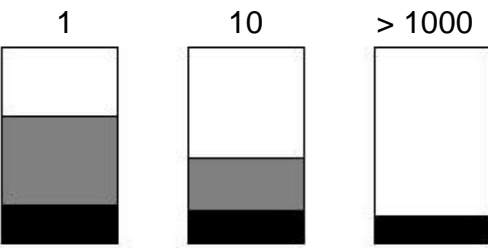

Fig. 6. Distribution between the three types of products as a function of the two parameters of pyrolysis $(\mathrm{G}=\mathrm{Gas}, \mathrm{T}=$ Tar, $\mathrm{C}=$ Char $)$

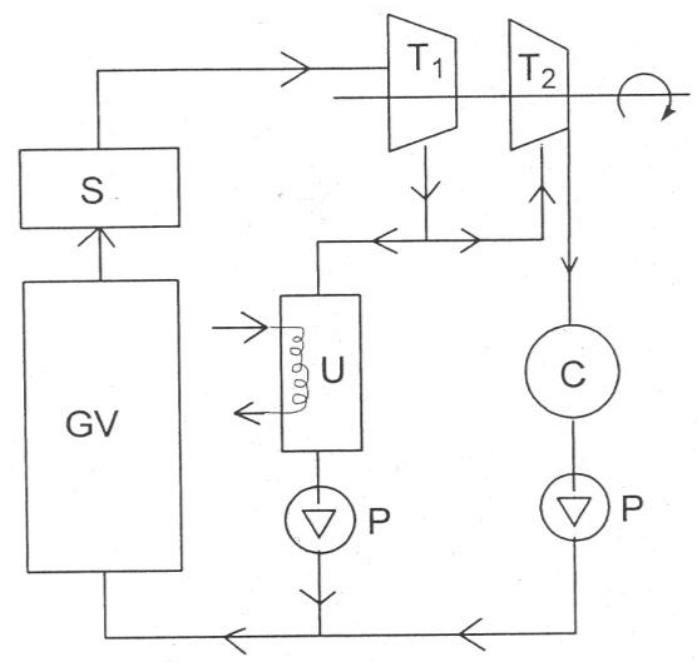

Fig. 8. Cogeneration steam cycle 